\title{
Gambaran Leukosit Pro Inflamasi pada Status Asmaticus di RSUD Kebumen
}

\author{
Pro Inflamatory Leukocyte Overview in Status Asthmaticus in Kebumen District Hospital \\ Ester Tri Rahayu ${ }^{1}$, Adika Zhulhi Arjana ${ }^{2 *}$ Juwariyah $^{1}$, Rahma Yuantari ${ }^{3}$, \\ Rozan Muhammad Irfan ${ }^{2}$ \\ ${ }^{1}$ Laboratorium Patologi Klinik, RSUD Kebumen \\ ${ }^{2}$ Fakultas Kedokteran, Universitas Islam Indonesia \\ ${ }^{3}$ Departemen Patologi Klinik, Fakultas Kedokteran, Universitas Islam Indonesia
}

\section{DATA NASKAH:}

Masuk: 23 Okt 2017

Direviu: 05 Nov 2017

Direvisi: 01 Des 2017

Diterima: 30 Des 2017

*KORESPONDENSI:

adika.zhulhi.a@uii.ac.id

DOI:

10.18196/mm.180108

TIPE ARTIKEL:

Penelitian

\begin{abstract}
Abstrak: Asma merupakan kondisi penyempitan jalan nafas yang selama ini hanya dianggap sebagai reaksi hipersensitifitas tipe 1 karena pada kondisi lain juga dapat disebabkan oleh inflamasi dan koagulasi. Pada hipersensitifitas tipe 1 terdapat peran neutrofil dan eosinofil dan dalam penelitin ini akan dipetakan fenotip asma berdasarkan aktifitas eosinof dan neutrofil yaitu eosinofilik dan neutrofilik pada serangan akut asma. Penelitian dilakukan dengan desain observasional retrospektif terhadap data sekunder pasien asma dewasa, dalam waktu 1 tahun kebelakang dengan sampel sebanyak 91 orang di RSUD Kebumen. Pengambilan data menggunakan data rekam medis. Analisis data menggunakan uji ANOVA untuk data terdistribusi normal, dan uji rerata Kuskal-Wallis untuk data tidak normal. Karakteristik subyek sejumlah 91 orang, dengan 31 subyek pria dan rerata umur 38 tahun. Delapan puluh empat persen subjek adalah asma derajat ringan, $4 \%$ berat dan sisanya sedang. Pada uji rerata eosinofil dan neutrofil, terdapat berbedaan rerata antar derajat serangan namun tidak signifikan secara statistik. Subyek asma neutrofilik lebih mendomasi dibandingkan eosinofilik. Walaupun begitu, belum dapat diambil kesimpulan hubungan kadar eosinofil dan neutrofil terhadap derajat asma karena belum ada hasil statistik yang signifikan.
\end{abstract}

Kata kunci: Eosinofil; Netrofil; Asma; Leukosit Pro Inflamasi

Abstract: Asthma is airway narrowing condition which only considered as type 1 hypersensitivity reactions due to another condition also can be caused by inflammation and coagulation. in type 1 hypersensitivity there is the role of neutrophils and eosinophils, and in this experiment will be mapped to phenotype of asthma based on eosinophil and neutrophil activities on acute attacks of asthma. The study was conducted using cross-sectional design of the adult asthma patients, within one year backward with a sample of 91 subject in Kebumen district hospital. Retrieving data using medical records. Data analyse with ANOVA for normally distributed data, and Kuskal-Wallis test for abnormal data. Characteristics subject of a number of 91 people, with 31 male subjects and a mean age of 38 years. $84 \%$ of the subjects with mild asthma, $4 \%$ by weight, and the rest are. On average test eosinophils and neutrophils, there is a degree to the difference between the average attack but was not statistically significant. Subjects neutrophilic asthma more dominate than eosinophilic.

Keywords: Eosinophil; Netrophil; Asthma; Pro Inflamatory Leukocyte 


\section{PENDAHULUAN}

Asma adalah kondisi penyempitan jalan nafas yang sifatnya reversible. ${ }^{1}$ Asma terjadi pada 4-5\% penduduk Amerika Serikat. Beban sosioekonomi yang terjadi cukup besar untuk pengobatan asma. Meskipun telah banyak kemajuan di bidang terapi asma namun angka mortalitas masih cukup tinggi. ${ }^{2}$ Asma selama ini dianggap sebagai penyakit akibat hipersensitifitas tipe I semata. Padahal studi lanjut menunjukkan bahwa asma juga merupakan penyakit yang berhubungan dengan inflamasi dan koagulasi. ${ }^{3}$ Fakta ini tentu menjadi terobosan dalam perbaikan tata laksana asma.

Pada hipersensitifitas tipe I belum diketahui secara jelas peran sel pro inflamasi seperti eosinofil dan neutrofil. Adanya aktivitas inflamasi yang ditemukan pada asma menjadi pintu gerbang untuk studi ini. Meskipun telah didukung oleh fakta ditemukannya sel pro inflamasi pada biopsi jaringan saluran nafas namun gambaran aktivitas kedua sel tersebut dalam darah belum diketahui. ${ }^{4}$ Diperlukan studi untuk memberikan gambaran jelas kondisi sel eosinofil dan neutrofil pada darah.

Eosinofil adalah sel imun yang sifatnya asam pada pengecatan Hematoxicillin eosin. Eosinofil terdapat dalam darah dalam jumlah yang sedikit yaitu 1-3 \% dari keseluruhan populasi leukosit. Eosinofil berperan dalam sistem imun terutama dalam melawan parasit. ${ }^{5}$ Eosinofil kadarnya dapat meningkat dalam tubuh. Beberapa obat juga memicu kenaikan eosinofil seperti emas, sulfonamid, dan penisilin., ${ }^{5,6}$ Eosinofil juga ditemukan meningkat pada kasus alergi seperti asma. Akan tetapi hal ini tidak terjadi pada asma yang bersifat non eosinofilik. ${ }^{5}$ Mekanisme kerja eosinofil menggunakan opsonisasi dengan dibantu oleh immunelobulin $E$ (IgE). Sehingga eosinofil sangat terkait kerjanya dengan IgE. ${ }^{7}$ Eosinofil setelah disintesis dan masuk aliran darah kemudian masuk menginfiltrasi jaringan. $^{8}$

Eosinofil juga berperan dalam proses inflamasi. Inflamasi sendiri terjadi dengan perantaraan sel T helper (Th). Selama ini diyakini sel Th2 adalah pemicu terjadinya inflamasi. Penelitian terbaru menunjukkan kehadiran sel Th17 sebagai sel prionflamasi. Sel Th17 merupakan sel yang mengaktivasi sel $T$ regulatory (Treg) yang sangat berperan dalam kondisi hipersensitifitas. Sel Th17 yang aktif akan mengekspresikan IL17. Interleukin ini bersama dengan interleukin lainnya kemudian menarik sel netrofil dan eosinofil ke lokasi inflamasi. Kedua sel tersebut kemudian mensekresikan beberapa kemokin dan sitokin seperti eritropoetin, TGF, matrix metalloproteinase. ${ }^{9}$
Neutrofil adalah seri leukosit yang merupakan perkembangan dari metamyelosit. Neutrofil memiliki 2 jenis bentuk yaitu band dan segment. Neutrofil bentuk band merupakan neutrofil yang telah matur namun memiliki aktivitas fagositosis yang lebih rendah dibanding bentuk segment. Neutrofil bentuk ini biasanya ada di dalam darah dalam jumlah yang sedikit yaitu $2 \%$ dari populasi leukosit. Adapun neutrofil bentuk segment berada dalam darah sekitar $50-70 \%$ dari populasi leukosit. Neutrofil segment biasanya mengandung 3-5 segmen dan memiliki kromatin yang tersebar di seluruh segmennya. Kromatin ini merupakan komponen aktif dari neutronfil dan dapat digunakan sebagai penanda aktivitas neutrophil. ${ }^{5}$

Neutrofil berperan dalam kekebalan tubuh dengan proses fagositosis. Fagositosis adalah proses eliminasi patogen dengan enzim lisozym yang ada dalam sel neutrofil. Aksi fagositosis sendiri perlu dirangsang oleh beberapa opsonin meskipun terdapat jenis reseptor tradisional yang dapat memicu proses fagositosis tanpa opsonin. ${ }^{7}$ Kenaikan jumlahnya disebabkan oleh peningkatan produksi yang bisa dipicu dengan kehadiran patogen khususnya bakteri. ${ }^{6}$ Selain itu neutrofil juga berperan dalam proses inflamasi dan vaskularisasi. ${ }^{7}$

Penelitian menunjukkan bahwa ada subtype dari $\mathrm{T}$ helper yang mengekspresikan IL-9. Subtype ini disebut dengan Th9, dengan sifat kerja yang berbeda dari Th17. Produk dari sel ini yaitu IL-9 memicu terjadinya bronkhus yang hiperresponsif. Keberadaan subset ini yang kemudian memicu infiltrasi eosinofil pada mukosa saluran nafas. ${ }^{4}$ Belum jelas bagaimana eosinofil bisa tertarik oleh IL-9. Namun studi menunjukkan populasi eosinofil yang banyak pada saluran nafas ketika Th9 diaktifasi. $^{10}$ Eosinofil yang aktif kemudian mengekskresikan exosome yang berisi lysobisphosphatidic acid (LBPA). Exosom ini yang kemudian menyebabkan terjadinya remodelling pada asma. ${ }^{11}$

Beberapa studi menunjukkan adanya respon eosinofil pada kondisi hipersensitifitas tipe I. Eosinofil terbukti bermigrasi ke endotel dan menginfiltrasi mukosa. Hal ini yang kemudian menyebabkan adanya inflamasi. ${ }^{12}$ Peranan eosinofil perlu ditelaah lebih lanjut untuk melihat responnya pada kondisi asma. Lebih lanjut hal ini perlu diteliti untuk melihat kondisi eosinofil ketika terjadi serangan asma.

Neutrofil sendiri peranannya dalam hipersensitifitas baru terdeteksi. Hal ini berdasarkan kondisi neovaskularisasi saluran nafas pada asma. Neutrofil yang tertarik oleh kehadiran IL-17A mengekspresikan IL-5 dan mediator lainnya. Diduga kehadiran netrofil berhubungan erat dengan beratnya sera- 
ngan, resistensi obat, dan remodelling saluran nafas yang terjadi. ${ }^{10,13}$

Sebuah penelitian menunjukkan bahwa kondisi asma tidak hanya masalah pada saluran nafas namun diduga vaskular ikut terlibat dalam patogenesisnya. Ditemukannya agen pro vaskularisasi seperti VEGF pada saluran nafas pasien asma adalah bukti hipotesis ini. Sebagaimana diketahui pula bahwa eosinofil adalah agen proinflamasi yang juga berperan dalam angiogenesis. ${ }^{3}$

Eosinofil yang distimulasi oleh IL-5 dengan kehadiran patogen membentuk eosinofil extracellular trap (EET). EET berfungsi sebagai pertahanan tubuh melawan patogen. Demikian juga halnya pada neutrofil membentuk neutrofil extracellular trap (NET) dengan stimulasi oleh toll like receptor (TLR)-4 agonis atau pelepasan komplemen C5a yang juga muncul pada pembentukan EET. Kedua trap ini bersifat sitotoksik pada patogen namun juga menyebabkan kerusakan pada jaringan pejamu. ${ }^{13}$ Namun belum jelas diketahui bagaimanakah karakter eosinofil dan neutrofil dalam darah ketika terjadi serangan akut asma.

\section{BAHAN DAN CARA}

Data yang diambil dalam penelitian ini adalah data rekam medis mencakup data pemeriksaan fisik oleh dokter dan data laboratorium yang terdapat pada rekam medis di RSUD Kebumen. Pasien yang masuk dirawat jalan maupun rawat inap dengan diagnosa status asmaticus.

Derajat serangan asma dikelompokkan menjadi ringan sedang, berat, dan mengancam jiwa. Pasien dengan derajat serangan asma ringan sedang memiliki gejala berupa masih bisa bicara 1 kalimat, lebih nyaman dengan posisi duduk, peningkatan laju nafas, denyut nadi 100-120 kali/menit, saturasi oksigen 90-95\%, nilai pulmonary expiration flow (PEF) $>50 \%$ dari yang diprediksi.

Derajat serangan berat memiliki gejala berupa masih bisa bicara dalam kata, duduk cenderung membungkuk ke depan, laju nafas >30 kali/menit, menggunakan otot bantu nafas tambahan, denyut nadi > 120 kali/menit, saturasi oksigen <90\%, nilai PEF $<50 \%$ dari yang diprediksi. Adapun derajat serangan mengancam jiwa adalah apabila pasien mengalami gelisah, bingung, ataupun tidak terdengar suara nafas dalam auskultasi. ${ }^{14}$

Data yang dikumpulkan diuji dengan uji rerata ANOVA dan uji Kruskal-Wallis. Data dianggap bermakna jika memenuhi nilai $\mathrm{p}<0,05$.

\section{HASIL}

Subyek yang terlibat dalam penelitian ini sejumlah 91 subyek. Subyek kesemuanya berasal dari pasien rawat inap RSUD Kebumen. Terdapat 31 subyek (34,07\%) pria dan 60 subyek wanita (65,93\%). Mayoritas dari subyek penelitian ini adalah wanita. Rerata usia subyek yang masuk dalam penelitian ini adalah 38 tahun. Untuk derajat serangan pada saat masuk secara merata pada ketiga derajat. Terbanyak adalah derajat ringan sebanyak $84 \%$ dan paling sedikit masuk pada derajat berat sebanyak $4 \%$. Mayoritas subyek tidak menggunakan reliever secara rutin pada saat serangan (79,12\%). Penggunaan controller juga tidak banyak, hanya 4 subyek $(4,39 \%)$ yang menggunakannya. Karakteristik subyek selengkapnya ada di Tabel 1 .

Karakter status eosinofil pada subyek cukup seragam pada berbagai derajat serangan. Hal ini tampak pada uji statistik dengan Kruskal Wallis menunjukkan nilai $p>0,05$. Artinya tidak ada perbedaan yang bermakna persentase eosinofil pada berbagai derajat serangan. Temuan ini juga tampak pada persentase netrofil, dengan nilai signifikansi 0,79 menunjukkan tidak ada perbedaan bermakna (lihat Tabel 2.).

Pengelompokan status eosinofil menjadi eosinofilia dan normal dilakukan untuk melihat proporsi kejadian eosinofilia pada berbagai derajat serangan asma. Tampak pada Tabel 3 bahwa mayoritas tidak terjadi eosinofilia. Proporsi cukup besar tampak pada derajat serangan 1 sebanyak 31,7\%. Secara keseluruhan tidak didapatkan perbedaan yang bermakna ditandai dengan $\mathrm{p}=0,83$.

Tabel 1. Karakteristik Subyek

\begin{tabular}{lcc}
\hline \multicolumn{1}{c}{ Karakteristik } & N $(\%)$ & Mean \pm SD \\
\hline Jenis Kelamin & & \\
Pria & $31(34,07 \%)$ & $38,92 \pm 18,82$ \\
Wanita & $60(65,93 \%)$ & \\
Usia & \\
Derajat Serangan & \\
Ringan & \\
Sedang & $77(84,62 \%)$ \\
Berat & $10(10,99 \%)$ \\
& $4(4,39 \%)$ \\
Penggunaan & \\
Reliever & \\
Ya & $19(20,88 \%)$ \\
Tidak & $72(79,12 \%)$ \\
Penggunaan & \\
Controller & \\
Ya & $4(4,39 \%)$ \\
Tidak & $87(95,60 \%)$ \\
\hline
\end{tabular}


Tabel 2. Karakteristik Eosinofil dan Netrofil pada Berbagai Derajat Serangan

\begin{tabular}{lcccc}
\hline & \multicolumn{3}{c}{ Derajat } & \multirow{2}{*}{ P } \\
\cline { 2 - 4 } & Ringan & Sedang & Berat & \\
\hline Eosinofil & $3,16 \pm 2,79 \%$ & $2,01 \pm 3,05 \%$ & $2,42 \pm 3,69 \%$ & 0,15 \\
Netrofil & $71,42 \pm 14,96 \%$ & $70,92 \pm 15,21 \%$ & $74,13 \pm 24,66 \%$ & 0,79 \\
\hline
\end{tabular}

Tabel 3. Karakter Netrofilia pada Berbagai Derajat Serangan

\begin{tabular}{|c|c|c|c|c|c|}
\hline & \multicolumn{3}{|c|}{ Derajat Serangan N (\%) } & \multirow{2}{*}{ Total } & \multirow{2}{*}{$\mathrm{P}$} \\
\hline & Ringan & Sedang & Berat & & \\
\hline Netrofilia & $36(60 \%)$ & $5(55,6 \%)$ & $3(75 \%)$ & $60,27 \%$ & 0,79 \\
\hline Tanpa Netrofilia & $24(40 \%)$ & $4(44,4 \%)$ & $1(25 \%)$ & $39,73 \%$ & \\
\hline
\end{tabular}

Tabel 4. Karakter Eosinofilia pada Berbagai Derajat Serangan

\begin{tabular}{|c|c|c|c|c|c|}
\hline & \multicolumn{3}{|c|}{ Derajat Serangan N (\%) } & \multirow{2}{*}{ Total } & \multirow{2}{*}{$\mathrm{P}$} \\
\hline & Ringan & Sedang & Berat & & \\
\hline Eosinofilia & $19(31,7 \%)$ & $2(22,2 \%)$ & $1(25 \%)$ & $30,14 \%$ & \\
\hline Tanpa Eosinofilia & $41(68,3 \%)$ & $7(77,8 \%)$ & $3(75 \%)$ & $69,86 \%$ & 0,83 \\
\hline
\end{tabular}

Pengelompokan juga dilakukan untuk status netrofilia. Hasil penelitian ini menunjukkan karakter yang berbeda dibandingkan eosinofilia. Mayoritas subyek pada berbagai derajat serangan menunjukkan kondisi netrofilia. Proporsi terbesar ada pada derajat serangan 3 yakni sebesar $75 \%$. Akan tetapi setelah dilakukan analisis menunjukkan tidak adanya perbedaan yang bermakna $(\mathrm{P}=0,79)$ (lihat Tabel 4.)

\section{DISKUSI}

Mayoritas subyek dalam penelitian ini adalah wanita $(65,93 \%)$. Hal ini sesuai dengan penelitian lain yang menunjukkan adanya kecenderungan subyek wanita yang mengalami eksaserbasi akut asma. American Lung Association yang melibatkan sebanyak 1612 subyek juga menemukan subyek wanita yang lebih banyak $63 \%$ dibandingkan subyek pria. ${ }^{15}$ Penelitian berbasis data lainnya yakni National Asthma Survey juga menemukan proporsi yang lebih tinggi yaitu $69,61 \%$ subyek wanita dari total 3060 subyek. Penyebab tingginya proporsi ini dimung kinkan karena adanya kepatuhan yang lebih tingg pada pria dalam pengobatan dibandingkan wanita. Selain itu faktor ekonomi juga memiliki peranan cukup besar. ${ }^{16,17}$

Rerata usia subyek pada penelitian ini merupakan usia dewasa muda. Hal ini juga sesuai dengan banyak penelitian lainnya. ${ }^{15,16} \mathrm{Hal}$ ini dimungkinkan karena tingkat kepatuhan penderita asma usia dewasa muda lebih rendah dibandingkan usia tua. Selain itu faktor merokok juga lebih mempengaruhi penderita asma usia tua. ${ }^{17}$

Subyek penelitian ini didominasi oleh derajat serangan ringan. Hal ini berbeda dengan penelitian yang dilakukan di Polandia dimana pasien asma yang datang ke UGD didominasi oleh penderita dengan derajat serangan sedang 49,29\%.' Perbedaan ini dimungkinkan karena tingkat pemahaman masyarakat Indonesia khususnya lokasi penelitian Kebumen yang masih rendah. Hal ini nampak dari penggunaan reliever dan controller yang masih sangat rendah pada populasi penelitian. Pemahaman yang baik terhadap asma tentu akan membuat jumlah kunjungan pasien ke UGD dengan derajat serangan ringan akan lebih sedikit.

Karakter eosinofil dan netrofil pada berbagai derajat serangan yang diuji dalam penelitian ini menunjukkan tidak adanya perbedaan bermakna dalam uji rerata. Eosinofil sendiri merupakan penanda aktifitas imun melawan parasit dan penyakit alergi. ${ }^{18}$ Peningkatan eosinofil pada kasus asma berhubungan dengan kerusakan mukosa dan bronkus yang hiperresponsif. Secara klinis hal ini nampak dalam beratnya serangan asma. Eosinofil mempengaruhi patofisiologi asma dengan cara meningkatkan lepasan mediator inflamasi seperti MBP, CysLTs, ROS dan sitokin. Peningkatan lepasan ini menyebabkan reaksi inflamasi pada asma yang lebih berat (12). Mediator yang dilepaskan juga menyebabkan bertahannya eosinofil dari proses apoptosis sehingga semakin meningkatkan jumlahnya. Proses ini diperantarai oleh Granulocyte-macrophage colony-stimulating factor (GM-CSF) yang dilepaskan oleh trombosit. ${ }^{19}$

Pada penelitian ini didapatkan bahwa ada perbedaan rerata persentase eosinofil pada berbagai derajat serangan. Derajat serangan berat memiliki rerata persentase tertinggi namun uji statistik tidak menunjukkan hasil signifikan. Penelitian menunjukkan tingginya kadar eosinofil lebih spesifik pada bilasan saluran nafas dibandingkan pada darah. ${ }^{13}$ Beberapa penelitian menunjukkan perbe- 
daan yang signifikan pada berbagai derajat namun bukan temuan yang spesifik sebagai prediktor beratnya serangan. ${ }^{20}$

Kondisi netrofilia pada subyek dalam penelitian ini menunjukkan adanya perbedaan reratapada berbagai derajat serangan. Netrofil sendiri berperan sebagaimana eosinofil dalam proses hiperreaktifitas bronkus. Pasien dengan netrofilia lebih banyak mengalami serangan berat dan ini berhubungan dengan reaktifitas pada metacoline. ${ }^{20}$ Netrofil juga berperan dalam remodelling vaskular pada kasus asma sehingga berhubungan dengan status kronis pasien asma. ${ }^{3}$

Secara umum pada subyek penelitian didapatkan karakter asma netrofilik yang dominan pada seluruh subyek (60,23\%). Karakter asma eosinofilik tidak banyak dijumpai pada subyek penelitian, hanya 30,14 \%. Temuan perbedaan rerata pada penelitian ini mendukung hipotesis bahwa karakter eosinofilia dan netrofilia berhubungan dengan derajat serangan asma. Meskipun demikian belum dapat disimpulkan bahwa ada hubungan yang erat karena tidak ada perbedaan yang signifikan secara statistik.

\section{SIMPULAN}

Subyek penelitian ini mayoritas memiliki karakter asma netrofilik, hanya beberapa yang memiliki karakter asma eosinofilik. Akan tetapi tidak terdapat perbedaan yang bermakna secara statistik kadar eosinofil dan netrofil pada berbagai derajat serangan asma.

\section{DAFTAR PUSTAKA}

1. Kasper DL, Fauci AS, Longo DL, Braunwald E, Hauser SL, Jameson JL. Harrison's Principles of Internal Medicine. 16th ed. The McGraw-Hill Companies; 2005.

2. Panek M, Mokros $Ł$, Pietras T, Kuna P. The Epidemiology of Asthma and Its Comorbidities in Poland - Health Problems of Patients with Severe Asthma as Evidenced in the Province of Lodz. Respir Med. 2016; 112:31-38.

3. Harkness LM, Ashton AW, Burgess JK. Asthma is Not Only an Airway Disease, but also a Vascular Disease. Pharmacol Ther, 2016;148: 17-33.

4. Saeki M, Kaminuma O, Nishimura T, Kitamura N, Mori A, Hiroi T. Th9 Cells Elicit EosinophilIndependent Bronchial Hyperresponsiveness in Mice. Allergol Int. 2016; 65: 24-29.

5. Theml H, Diem H, Haferlach T. Color Atlas of Hematology. Thieme. 2004. 1-5.

6. Provan D. Oxford Handbook of Clinical Haematology. Medicine (Baltimore), 2009; 98 (6):
920-925.

7. Gorczynski R, Stanley J. Clinical Immunology. Clinical inmunology. 2013.

8. Cruse JM, Lewis RE. Illustrated dictionary of immunology. 2003.

9. Hoppenot D, Malakauskas K, Lavinskienè S, Bajoriūnienė I, Kalinauskaitė V, Sakalauskas R. Peripheral Blood Th9 Cells and Eosinophil Apoptosis in Asthma Patients. Medicina (B Aires). 2015; 51 (1): 10-17.

10. Lukawska JJ, Livieratos L, Sawyer BM, Lee T, O'Doherty M, Blower PJ, et al. Imaging Inflammation in Asthma: Real Time, Differential Tracking of Human Neutrophil and Eosinophil Migration in Allergen Challenged, Atopic Asthmatics in Vivo. EBioMedicine. 2014; 1 (2): 173-180.

11. Mazzeo C, Cañas JA, Zafra MP, Rojas Marco A, Fernández-Nieto $\mathrm{M}$, Sanz $\mathrm{V}$, et al. Exosome Secretion by Eosinophils: A Possible Role in Asthma Pathogenesis. J Allergy Clin Immunol, 2015; 135 (6): 1603-1613.

12. Athari SS, Athari SM. The Importance of Eosinophil, Platelet and Dendritic Cell in Asthma. Asian Pacific J Trop Dis, 2014; 4: S41-7.

13. Dworski R, Simon H-U, Hoskins A, Yousefi S. Eosinophil and Neutrophil Extracellular DNA Traps in Human Allergic Asthmatic Airways. J Allergy Clin Immunol, 2011 [cited 2016 Oct 5]; 127 (5): 1260-1266.

14. Global Initiative for Asthma. Pocket Guide for Asthma Management and Prevention. 2016.

15. McCallister JW, Holbrook JT, Wei CY, Parsons JP, Benninger CG, Dixon AE, et al. Sex Differences in Asthma Symptom Profiles and Control in the American Lung Association Asthma Clinical Research Centers. Respir Med [Internet]. 2013; 107 (10): 1491-1500.

16. Temprano J, Mannino DM. The Effect of Sex on Asthma Control from the National Asthma Survey. J Allergy Clin Immunol [Internet]. 2009; 123 (4): 854-860.

17. Chaudhuri R, McSharry C, Heaney LG, Niven R, Brightling CE, Menzies-Gow AN, et al. Effects of Older Age and Age of Asthma Onset on Clinical and Inflammatory Variables in Severe Refractory Asthma. Respir Med [Internet]. 2016; 118: 46-52.

18. Mehta AB, Hoffbrand AV. Haematology at a Glance. 2014.

19. Btech VV. Inhibition of Eosinophil Apoptosis by Asthma-Relevant Cytokines from Platelets. J Allergy Clin Immunol, 2015; 136 (4): 1134-1139.

20. Fahy J V. Eosinophilic and Neutrophilic Inflammation in Asthma: Insights from Clinical Studies. Proc Am Thorac Soc, 2009; 6 (3): 256-259. 